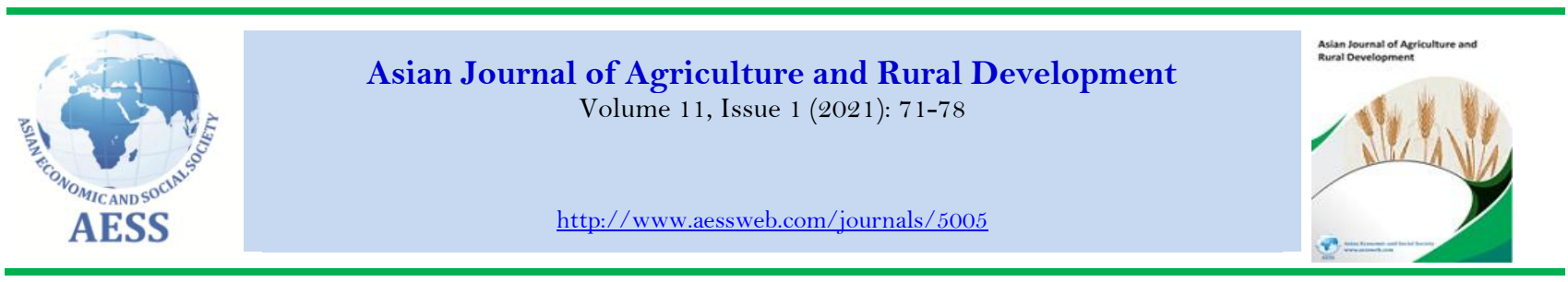

\title{
THE IMPACT OF FINANCIAL FACTORS ON THE AFTER-SALES SERVICE OF AGRICULTURAL MACHINERY: A CASE STUDY OF CHINESE AGRICULTURAL MACHINERY IN SOUTH AFRICA
}

\section{iD Xiaoshun Qin ${ }^{\mathrm{a}}$ \\ Dongdong Jiang ${ }^{\mathrm{b}}$ \\ Leon Pretorius ${ }^{\mathrm{c}}$}

\section{Article History}

Received: 16 December 2020

Revised: 6 January 2021

Accepted: 21 January 2021

Published: 4. February 2021

\section{Keywords}

After-sales service

Agricultural machinery

Economic factors

Financial resources. a., Department of Engineering and Technology Management, University of Pretoria, Pretoria, South Africa.

\section{ه dongdongjiang1212@,163.com (Corresponding author)}

\begin{abstract}
Compared to other countries, the level of agricultural mechanization in Africa and South Africa is relatively low. Among the factors that influence agricultural mechanization, after-sales service of agricultural machinery is among the most significant. On the other hand, financial resources primarily impact on improvement and enhancement of aftersales service of farm equipment. In this paper, a questionnaire was employed as the method of quantitative data collection to assist in the analysis of data from 739 respondents in the Chinese context. Due to the Covid-19 pandemic in 2020 (Mmbengwa \& Qin, 2020), no questionnaires were collected from South Africa for the purposes of this paper. A standard multiple regression analysis (MRA) was utilized to analyze the data collected from the structured questionnaires. Evidence from this study suggests that combining these financial resource factors has a major effect $\left(F^{2}=0.802\right)$ on the after-sales service of farm equipment. The high scores obtained for economic factors and analyzed in this study mean that, to a large extent, these have a major impact on China's after-sales service for agricultural machinery in South Africa.
\end{abstract}

Contribution/Originality: This study is one of the very few researches to explore the impact of financial resource factors on the after-sales service of Chinese agricultural machinery in South Africa. However, the research results show that financial resources positively influence these services. Furthermore, this study's outcome and impact will have a positive influence in terms of sustainable agri-enterprises and agricultural economic growth.

DOI: 10.18488 /journal.ajard.2021.111.71.78

$\operatorname{ISSN}(\mathrm{P}): 2304-1455 / \operatorname{ISSN}(\mathrm{E}): 2224-4433$

How to cite: Xiaoshun Qin --- Dongdong Jiang --- Leon Pretorius (2021). The Impact of Financial Factors on the After-Sales Service of Agricultural Machinery: A Case Study of Chinese Agricultural Machinery in South Africa. Asian Journal of Agriculture and Rural Development, 11(1), 71-78. 10.18488/journal.ajard.2021.111.71.78 (C) 2021 Asian Economic and Social Society. All rights reserved.

\section{INTRODUCTION}

Growth in agricultural productivity is a very worthwhile goal, resulting in robust leverage of hunger alleviation, poverty reduction, and an improved labor market. This is especially important in countries with relatively low agricultural productivity, such as in Africa (Qin, Pretorius, \& Jiang, 2019). Therefore, facilitating agricultural development and improving productivity in agriculture should be considered as key and crucial roles in increased industrialization in Africa, including South Africa. In a bid to promote enhanced agricultural industrialization, the aftersales service (ASS) of agricultural machinery (AM) plays a significant role in the agrarian mechanization of South Africa (Adu-Baffour, Daum, \& Birner, 2019; Qin, Zhang, \& Mmbengwa, 2020b; Sims \& Kienzle, 2016). 
One of the main issues regarding agricultural machinery in Africa is that of ASS, which is crucial and essential to agricultural mechanization as it can decrease the utilization of physical labor, improve farm plant productivity, boost agricultural efficacy, enhance the effective and efficient use of resources, ameliorate market access, and contribute to mitigating climate-related hazards (Kirui \& Braun, 2018; Mrema, Kienzle, \& Mpagalile, 2018; Van Loon et al., 2020). Moreover, as more and more Chinese AM emerges in Africa and South Africa, the ASS of farm equipment (Qin et al., 2019) is very important because lack of service will severely impact agricultural production.

Among the factors that impact the ASS of AM, financial aspects have become among the most significant. The economic factors affecting ASS of AM in this study include savings (Duguma \& Han, 2018), overdraft (Melzer \& Morgan, 2015) and access to credit (Awotide, Abdoulaye, Alene, \& Manyong, 2015; Cingano, Leonardi, Messina, \& Pica, 2016; Heikkilä, Kalmi, \& Ruuskanen, 2016), sponsorship (Lundh, Lexchin, Mintzes, Schroll, \& Bero, 2017), and grants (Creamer, 2015).

Although numerous researchers have focused on agri-mechanization in Africa, few have concentrated on the impact of financial resource factors on the ASS of AM. The broad aim of this study was to establish a new risk-reduction model of ASS of Chinese AM in South Africa. In the context of this study, the focus is on the influence of resource factors on ASS.

The main objective of the research presented in this paper is to explore the impact of financial factors on the ASS of Chinese AM (Qin et al., 2019) in South Africa, as part of a new model of ASS risk reduction regarding AM. In a bid to meet this objective, quantitative data collection and analysis were employed to examine the relationship between these factors. The accomplishment of our aim in this study may benefit the agriculture industry and relevant government policy-makers, to assist them in adjusting enterprise strategy and government policy formulation.

The following sections are: literature review, research methodology, study results and data analysis, conclusion, recommendations and acknowledgments.

\section{LITERATURE REVIEW}

After-sale service is regarded as an increasing and essential concept in many industries for establishing good customer relationships that contribute to increasing performance for sustainable results (Chiguvi, 2020; Murali, Pugazhendhi, \& Muralidharan, 2015; Shokouhyar, Shokoohyar, \& Safari, 2020). Moreover, Han (2005) and Fu and Cheng (2010) state that the ASS of AM represent all the technical services provided by the sales department as well as sales division's service management. On the other hand, Zhang (2010) defines the ASS as to debugging of AM, maintenance, repairs, troubleshooting, provision of technical support, delivering production, offering information for improvement and upgrading, and access to customer feedback on agricultural products and services.

According to Qin et al. (2019), the factors involved in the ASS of AM include experts/technicians, timely repairs, spare parts, maintenance, training courses, and user information systems. On the other hand, financial resources play a highly significant role in the development of enterprises all over the world. Meanwhile, financial resources are also extremely crucial to the development and sustainability of farm equipment enterprises. Furthermore, the economic factors affecting ASS of AM in this study include savings (Duguma \& Han, 2018), overdraft facilities (Melzer \& Morgan, 2015), access to credit (Awotide et al., 2015; Cingano et al., 2016; Heikkilä et al., 2016), sponsorship (Lundh et al., 2017), and grants (Creamer, 2015), as mentioned in the Introduction.

First, many enterprises face the issue of increasing overhead costs and make efforts to reduce these, which is a basis for the use of outsourcing principles to provide and increase savings (Potkány, Stasiak-Betlejewska, Kováč, \& Gejdoš, 2016), attending to the core business having become the priority in enterprise development (Potkány et al., 2016)). Meanwhile, Wieliczko, Kurdyś-Kujawska, and Sompolska-Rzechuła (2020) demonstrated that savings are a catalyst for capital creation and are the driving force behind economic growth and development. As savings are crucial for the welfare, sustainability, increased competitiveness, and development of an agricultural enterprise, an understanding of what makes these more diverse can help identify appropriate support schemes set up by those companies for whom sustainable development projects are important (Wieliczko et al., 2020). Second, some statistics and research show that among the resources most used for finance companies is a bank loan or overdraft (Mladenka, Slobodan, \& Periša, 2016). Furthermore, Mladenka et al. (2016) state that the use of overdrafts is most prevalent among large enterprises (with at least 250 employees) and lowest among micro-enterprises (1 to 9 employees). Overdraft facilities are also crucial to the development of enterprises and risk reduction in AM companies. Third, Mabururu and Wekesa (2020) explain that a major hindrance to entrepreneurship and enterprise development is access to funds. Enterprise development funds have led to enhanced performance of enterprises, and therefore the socio-economic status of their managers shows improvement due to access to loans (Mabururu \& Wekesa, 2020). On the other hand, Ogundeji, Donkor, Motsoari, and Onakuse (2018) conclude that adequate access to credit is necessary to promote sustainable agricultural development and the livelihoods of rural farmers in Africa. Fourth, Fotiadis, Nuryyev, Achyldurdyyeva, and Spyridou (2019) indicate that one way to acquire sponsorship is to access national or local government programs. In addition, the development of sponsorship programs that diversify the economic structure of rural communities businesses make them less vulnerable to changes in market conditions (Fotiadis et al., 2019). The sponsorship obtained from government or an association is crucial for the growth and development of agricultural enterprises. Finally, Dvouletý, Srhoj, and Pantea (2020) elaborate that governments allocate financial resources to support small- and medium-sized enterprises (SMEs) through public subsidies and grants to increase their performance and growth (Dvouletý et al., 2020). However, grants are less cost efficient when compared to other financial instruments (Dvouletý et al., 2020). There is a long tradition of allocating public grants as a direct form of support to firms and entrepreneurs in a bid to increase their growth and improve their financial performance and efficiency (Dvouletý et al., 2020). 
In conclusion, the literature shows that savings, overdrafts, access to credit, sponsorship, and grants are significant factors in enterprise development and growth. In the next section, the influence of and relationships between those financial factors and the ASS of AM will be elaborated upon in detail.

\section{METHODOLOGY}

The research methodology employed in this study is detailed in this section.

\subsection{Research Design}

The study for this paper applied a quantitative (Creswell \& Creswell, 2017; Kidd, Wengstro, \& Ulrika, 2011; Terrell, 2012) research design, which makes it possible to collect quantitative data by means of questionnaires. The quantitative data for this paper were collected from Shandong and Henan provinces in China, two of the biggest AM manufacturing provinces. Quantitative data gathering was also planned to be obtained in South Africa in a bid to compare the data acquired from those two countries, but unfortunately this had to be cancelled due to the Covid-19 pandemic (Qin et al., 2019; Zhang. \& Qin, 2020) that started in China and South Africa in December 2019. This will now be considered as part of future research for the extended research project.

The analysis method of quantitative data employed in the research for this paper is multiple regression analysis (MRA) (Hossain, Zyroul, Pereira, \& Kamarul, 2012; Ngo \& Puente, 2012; Yarnold \& Bennett, 2016). MRA refers to a statistical analysis method in which one variable is regarded as the dependent variable while the other variables are considered as independent variables (Keith, 2019); moreover, the quantitative relationship between linear or nonlinear mathematical models among multiple variables is established, and the sample data collected in China were used for analysis (Keith, 2019). In conclusion, this quantitative research explored the socio-economic impact of financial factors on ASS of Chinese AM in South Africa by means of the methodology mentioned above.

\subsection{Research Population, Sample Strategy, and Research Participants}

The research population in this study included staff, workers, directors, managers, CEOs, and presidents working in agricultural machinery enterprises; government officials, staff, and directors who research agricultural machinery and provide services and knowledge for agri-machinery users; academics including professors, doctors, and researchers whose research is on ASS of AM; smallholder farmers or users of farm machinery in China; and other relevant people involved in ASS of AM.

In this study, probability sampling was used as shown in Figure 1; furthermore, simple randomized probability sampling strategies were employed to devise sampling that represented the sample population associated with our research study (Qin et al., 2019). The sample used in this study was initially chosen randomly from the personnel base mentioned above, followed by questionnaires formulated by employing the principles of non-probability sampling techniques such as snowball and purposive sampling (Qin et al., 2019).

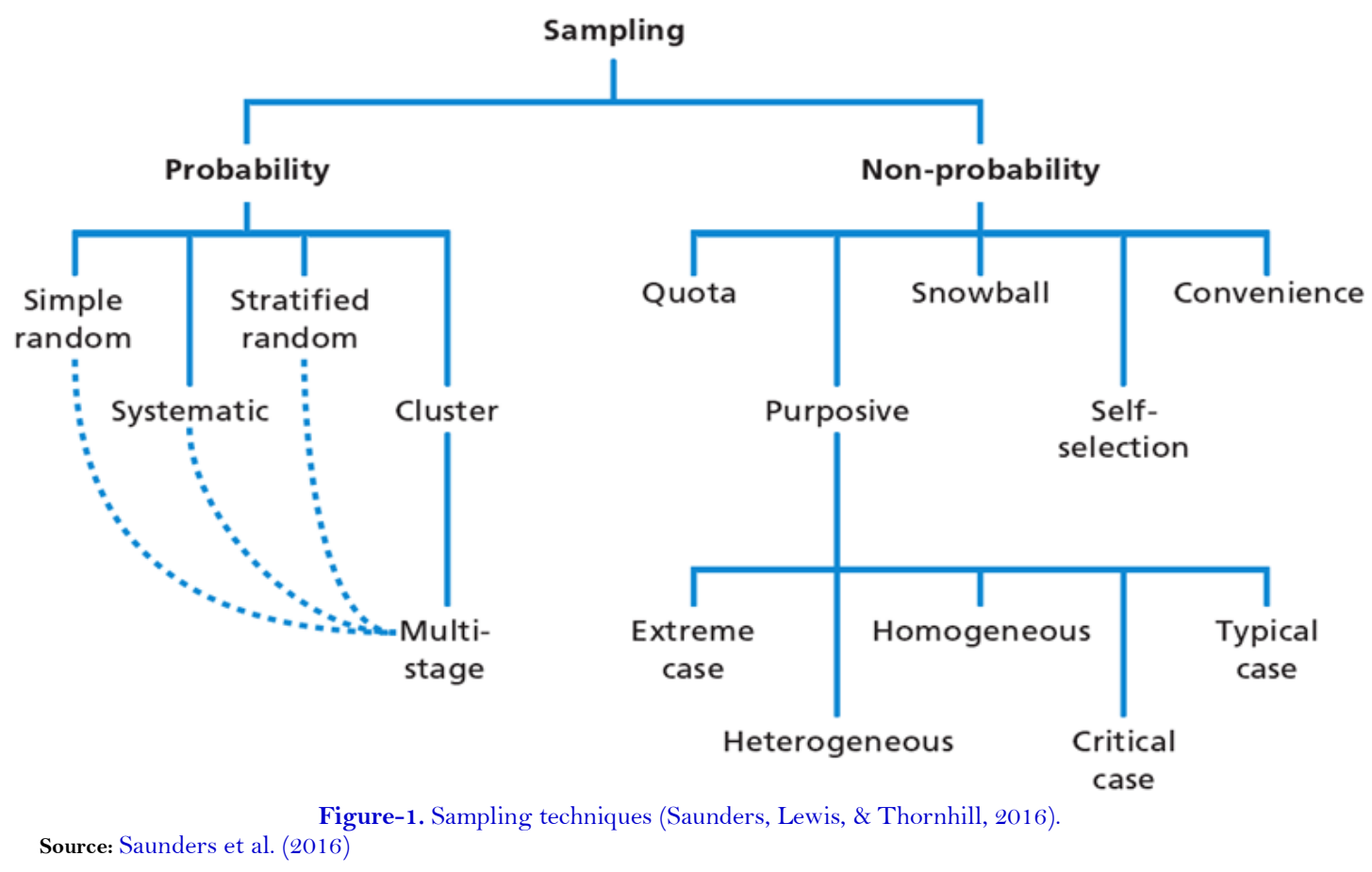

The research participants involved in this study are representative of the research population mentioned above.

\subsection{Data Collection Method}

The method of data collection employed in this study is the structured questionnaire. Unlike semi-structured or unstructured interviews, a questionnaire works best with standardized questions interpreted in the same way by all 
respondents (Saunders et al., 2016). Questionnaires, therefore, tend to be used for descriptive or explanatory research (Saunders et al., 2016). The choice of questionnaire used in this research is a method appropriate and suitable to answering the research question(s) and objectives via the relevant data collection.

The total of 384 questionnaires available were collected in Shandong province, China, while another 355 were obtained from Henan province; these provinces host two of the largest agriculture machinery manufacturers. The data collected from China thus comprise 739 questionnaires which were analyzed in a bid to answer the research questions and meet the research objectives.

\subsection{Data Analysis Method}

As mentioned above, the analysis method employed in this research is MRA (Hossain et al., 2012; Ngo \& Puente, 2012; Yarnold \& Bennett, 2016). The financial resources for ASS of AM (Qin et al., 2019) are treated as the dependent variable in the data analysis process, while values including savings, overdrafts, and access to credit, sponsorship, and grants are regarded as the independent variables. MRA was employed to predict and reveal the relationship of financial resource of ASS of Chinese AM in South Africa.

\section{RESULTS AND DISCUSSION}

\subsection{Demographics of Research Participants}

The demographic profiles of the research participants include four items: age, gender, position in the company or institute, and working years of business experience. Descriptive analysis was employed to comprehensively explore and display these four items in terms of frequency, percentage, and cumulative percentage. The item age includes five items: <20, 20-29, 30-39, 40-49, and 50+ years of age (Table 1); Table 2 illustrates the item gender. The item participant's position consists of five items: CEO, senior manager, manager, specialist, and other, as shown in Table 3. Business experience (in years) is also shown in more detail in Table 4.

Table 1 reveals that the majority of participants were aged 30-39 years (32.9\%), followed closely by those aged 40-49 (31.7\%). The third and fourth age categories were $20-29(16.5 \%)$ and $50+$ years $(16.1 \%)$, as shown in Table 1 . The smallest group was the youngest (<20 years).

Table-1. Age of study participants

\begin{tabular}{c|c|c|c|c|c}
\hline \multicolumn{2}{c|}{ Age (years) } & Frequency & Percentage & Valid percentage & Cumulative percentage \\
\hline \multirow{4}{*}{} & $<20$ & 21 & 2.8 & 2.8 & 2.8 \\
\cline { 2 - 6 } & $20-29$ & 122 & 16.5 & 16.5 & 19.4 \\
\cline { 2 - 6 } & $30-39$ & 243 & 32.9 & 32.9 & 52.2 \\
\cline { 2 - 6 } & $40-49$ & 234 & 31.7 & 31.7 & 83.9 \\
\cline { 2 - 6 } & $\geq 50$ & 119 & 16.1 & 16.1 & 100.0 \\
\hline
\end{tabular}

In this study, gender participation was skewed toward male respondents, implying that males dominate in AM entrepreneurship in China. According to Table 2, males constitute the majority (72\%). This observation may imply that the industry is not well represented in terms of gender when other conditions for transformation are held constant.

Table-2. Gender of study participants.

\begin{tabular}{c|c|c|c|c|c}
\hline \multicolumn{2}{c|}{ Gender } & Frequency & Percentage & Valid percentage & Cumulative percentage \\
\hline \multirow{4}{*}{ Male } & 532 & 72.0 & 72.0 & 72.0 \\
\cline { 2 - 6 } & Female & 207 & 28.0 & 28.0 & 100.0 \\
\cline { 2 - 6 } & Total & 739 & 100.0 & 100.0 & \\
\hline
\end{tabular}

According to Table 3, specialists comprise the majority (38.3\%) of participants, followed by senior managers (23.3\%) and managers (19.1\%) (Qin et al., 2019); the lowest category is other (8.5\%), with CEO at $10.8 \%$.

Table-3. Participants' employment position.

\begin{tabular}{c|c|c|c|c|c}
\hline \multicolumn{2}{|l|}{ Position } & Frequency & Percentage & Valid percentage & Cumulative percentage \\
\hline \multirow{4}{*}{ CEO } & 80 & 10.8 & 10.8 & 10.8 \\
\cline { 2 - 6 } & Senior manager & 172 & 23.3 & 23.3 & 34.1 \\
\cline { 2 - 6 } & Manager & 141 & 19.1 & 19.1 & 53.2 \\
\cline { 2 - 6 } & Specialist & 283 & 38.3 & 38.3 & 91.5 \\
\cline { 2 - 6 } & Other & 63 & 8.5 & 8.5 & 100.0 \\
\hline
\end{tabular}

From Table 4 it will be seen that business experience of $6-10$ years (20.7\%) is the highest category, followed by 0-5 (18.9\%), 11-15 (16.8\%), and 16-20 years (14.1\%). 
Table-4. Participants' business experience.

\begin{tabular}{c|c|c|c|c|c}
\hline Experience (years) & Frequency & Percentage & Valid percentage & Cumulative percentage \\
\hline & $0-5$ & 140 & 18.9 & 18.9 & 18.9 \\
\cline { 2 - 6 } & $6-10$ & 153 & 20.7 & 20.7 & 39.6 \\
\cline { 2 - 6 } & $11-15$ & 124 & 16.8 & 16.8 & 56.4 \\
\cline { 2 - 6 } & $16-20$ & 104 & 14.1 & 14.1 & 70.5 \\
\cline { 2 - 6 } & $21-25$ & 90 & 12.2 & 12.2 & 82.7 \\
\cline { 2 - 6 } & $26-30$ & 72 & 9.7 & 9.7 & 92.4 \\
\cline { 2 - 6 } & $>30$ & 56 & 7.6 & 7.6 & 100.0 \\
\hline
\end{tabular}

\subsection{Results and Discussion}

The factors that affect financial resources are denoted by FR-C6 (financial resources, the sixth item in group C; there are four groups in the questionnaire - A-D) for the ASS of AM, and are presented in Table 5 . These factors were estimated using MRA, as indicated previously. Multiple regression (Morrissey \& Ruxton, 2018; Pallant, 2020; Valaskova, Kliestik, \& Kovacova, 2018) is a suite of research techniques that can be employed to explore the relationship between one continuous, dependent variable and a set of independent variables. In standard multiple regression, all the independent variables are entered into the model simultaneously (Pallant, 2020). Each independent variable is assessed in terms of its predictive power, over and above that provided by all the other independent variables (Pallant, 2020).

The use of MRA is appropriate after the assumption of normality (see Figures 2 and 3) and homoscedasticity (see Figure 4) are met. On the one hand, Rani (2016) states that the most commonly used statistical methods are correlation, regression, and experimental design (Littlejohn \& Dutant, 2020; Schmidt \& Finan, 2018). However, these are all based on one basic assumption, that the observation follows normal (Gaussian) distribution (Littlejohn \& Dutant, 2020; Rani, 2016). Inferential methods require checking the normality of assumption prior to further discussion (Rani, 2016). Generally, histograms, percent-percent $(\mathrm{P}-\mathrm{P})$ plots and quantile-quantile $(\mathrm{Q}-\mathrm{Q})$ plots have the greatest application for normality assumption checking (Rani, 2016). In this research, application of the histogram (Figure 2) and P-P plots (Figure 3) well illustrate the normality of financial resources that influence risk reduction regarding agricultural machinery.

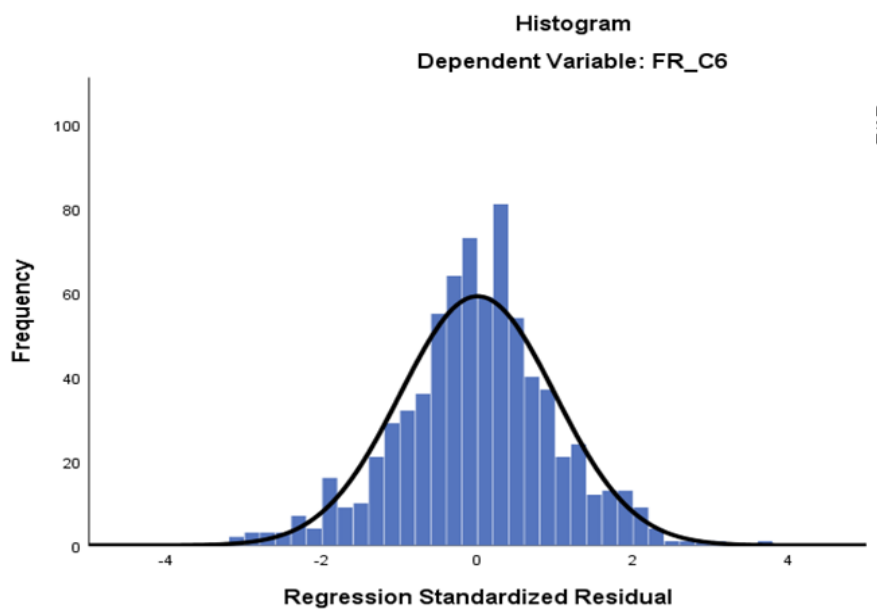

Mean $=4.22 E-16$
Strd Deve. $=0.997$
$N=739$

Figure-2. Histogram of the normality of the factor financial resources

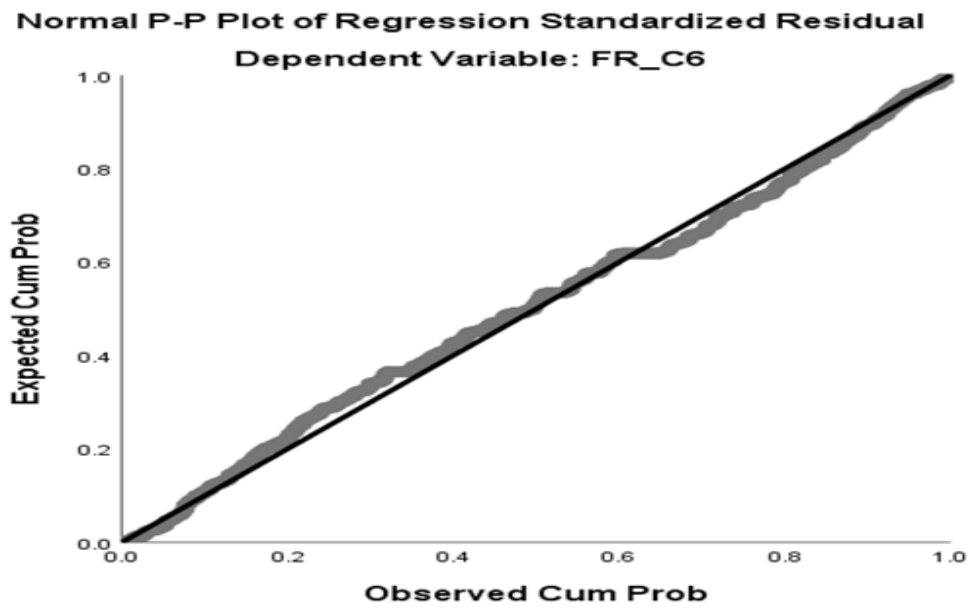

Figure-3. P-P plot of the normality of the factor financial resources. 
On the other hand, homoscedasticity (Yang, Tu, \& Chen, 2019) refers to a condition in which the variance of the residual, or error term, in a regression model is constant. When the condition of homoscedasticity (equal variances) is not met, it is expected that the variance of each data point may be quite different (Barbosa et al., 2018). However, Figure 4 shows the excellent fit for homoscedasticity of financial resources.

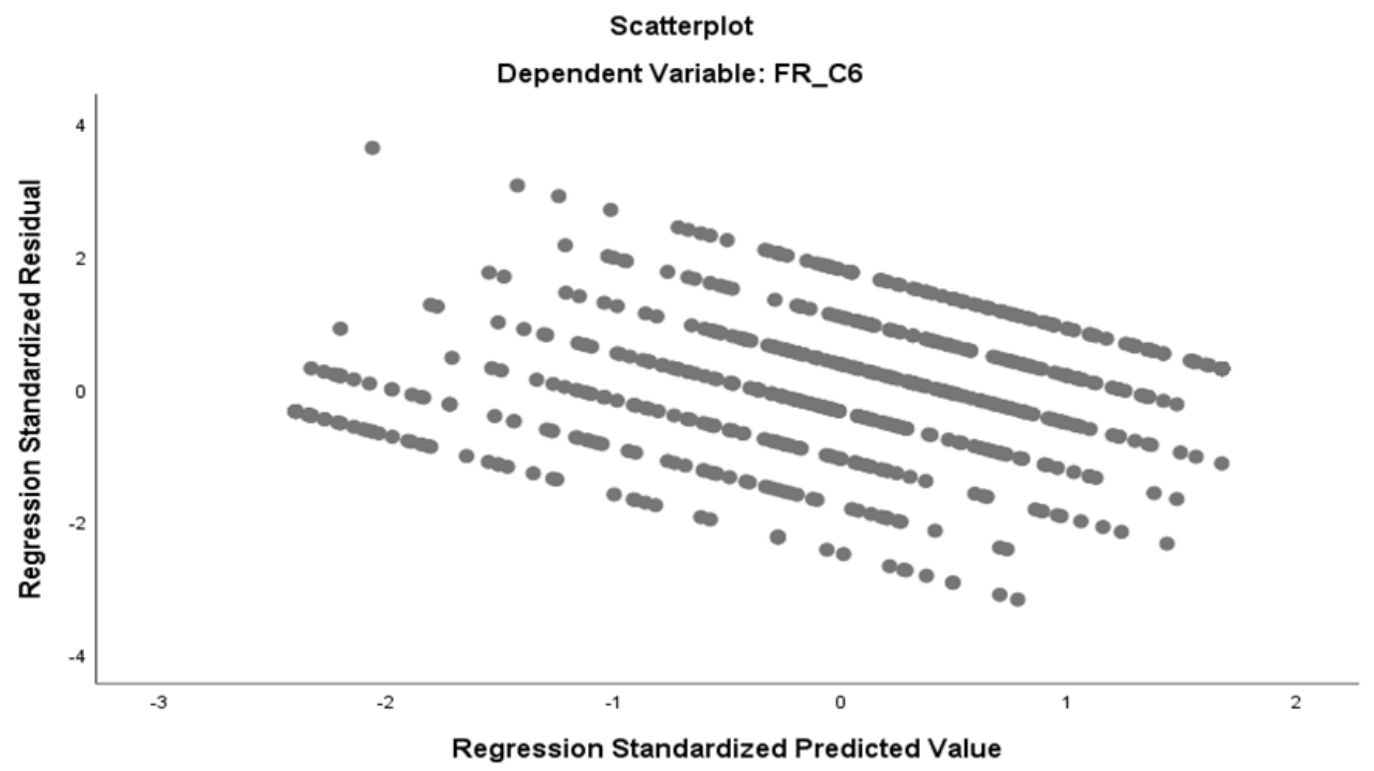

Figure-4. P-P plot of the homoscedasticity of the factor financial resources.

Table 5 reveals that the combination of the identified factors is significant $[F(5,739)=117.437, p=0.000]$, and represents $44.5 \%$ variability of the financial resources variable $\left[R^{2}=0.445\right.$, adj. $\left.R^{2}=0.441\right]$. The study also shows that combining these factors has a large effect $\left(F^{2}=0.802\right)$ on ASS of AM. Given the beta estimates, it is revealed that access to grants (beta $=0.374, p=0.000$ ) has the most significant impact on financial resources of the ASS of AM, followed by sponsorship (beta $=0.154, p=0.000$ ) and access to credit (beta $=0.153, p=0.002)$. On the other hand, Savings and overdraft facilities are found to be insignificant at $p=0.05$, which means they are relatively insignificant in comparison with other financial factors. These findings are supported by Heyer, Schmitt, Dombrowski, and Yarosh (2020), who emphasized that growth in most businesses is due to access to credit facilities, grants, and sponsorship. Heyer et al. (2020) and Omondi-Ochieng (2020) report that donation and sponsorship account for $87.5 \%$ of enterprises' financial performance.

Table-5. Factors affecting financial resources (FR-C6) of ASS of AM.

\begin{tabular}{|c|c|c|c|c|c|c|c|c|}
\hline Factors & B & Beta & $P$-value & \multicolumn{2}{|c|}{$[95 \% \mathrm{CI}]$} & Part (sr) & Tolerance & VIF \\
\hline (Constant) & 0.635 & & 0.000 & 0.300 & 0.969 & & & \\
\hline Savings & 0.071 & 0.071 & 0.053 & -0.001 & 0.142 & 0.053 & 0.569 & 1.758 \\
\hline Overdraft & 0.086 & 0.084 & 0.072 & -0.008 & 0.180 & 0.050 & 0.348 & 2.876 \\
\hline Access to credit & 0.160 & 0.153 & 0.002 & 0.059 & 0.262 & 0.085 & 0.311 & 3.213 \\
\hline Sponsorship & 0.160 & 0.154 & 0.000 & 0.072 & 0.248 & 0.099 & 0.411 & 2.435 \\
\hline Grant & 0.372 & 0.374 & 0.000 & 0.304 & 0.439 & 0.298 & 0.636 & 1.573 \\
\hline
\end{tabular}

Table 6 shows that the value of the impact of financial resource on the ASS of AM is 4.48, which is higher than the mean (3.0). The Likert scale used in this study was measured from 1 to 7 (no influence $=1$, highly influential $=7$ ). The score of FR-C6 means that financial resources markedly influence the ASS of AM in South Africa, as seen from the perspective of China.

Table-6. The impact of financial resources on the ASS of AM

\begin{tabular}{c|c|c|c|c|c|c|c}
\hline & $\boldsymbol{N}$ & Minimum & Maximum & Mean & \multicolumn{2}{c}{ Std. deviation } & \multicolumn{2}{c}{ Skewness } \\
\cline { 2 - 7 } & Statistic & Statistic & Statistic & Statistic & Statistic & Statistic & Std. error \\
\hline FR-C6 & 739 & 1 & 7 & 4.48 & 1.875 & -0.316 & 0.090 \\
\hline Valid N (listwise) & 739 & & & & & \\
\hline
\end{tabular}

\section{CONCLUSION}

The study employs a quantitative data gathering and analysis methodology to examine the relationship between financial resources and ASS of Chinese AM in South Africa (Qin et al., 2019). A questionnaire was used as the 
measurement instrument to collect quantitative data from 739 participants in the study, in China. Multiple regression analysis was employed to analyze the data collected from the structured questionnaires.

Evidence from the study suggests that the combination of financial resource factors has a large effect $\left(F^{2}=0.802\right)$, as shown in Table 5. The high score found for FR-C6 means that financial resources seem to exert a marked influence on the ASS of AM in South Africa, as seen from China's perspective (Table 6).

In future research, both quantitative and qualitative data collection and data analysis will be employed to examine the relationships among financial resources, AM risk reduction, sustainable agri-enterprise, and agricultural economic growth, in a bid to explore and validate the risk reduction model of ASS of Chinese AM in South Africa (Qin et al., 2019). Inclusion of research input from a future survey in South Africa might also be beneficial. Finally, this research provides an empirical contribution to the socio-economic sphere and literature and which can benefit the South African and Chinese agricultural economy and policy-making sectors.

Funding: This study received no specific financial support.
Competing Interests: The authors declare that they have no competing interests.
Contributors/Acknowledgement: The authors would like to thank the participants in
Shandong and Henan provinces who were involved and devoted themselves to this research
outcome by completing the questionnaires efficiently and effectively. Further appreciation is
also due to the Henan Bureau of Agricultural Machinery, who assisted in obtaining data. Finally,
thanks are also due to the University of Pretoria for study support and data analysis mentoring.
Views and opinions expressed in this study are those of the authors views; the Asian Journal of
Agriculture and Rural Development shall not be responsible or answerable for any loss, damage,
or liability, etc. caused in relation to/arising out of the use of the content.

\section{REFERENCES}

Adu-Baffour, F., Daum, T., \& Birner, R. (2019). Can small farms benefit from big companies' initiatives to promote mechanization in Africa? A case study from Zambia. Food Policy, 84(C), 133-145.Available at: https://doi.org/10.1016/j.foodpol.2019.03.007.

Awotide, B. A., Abdoulaye, T., Alene, A., \& Manyong, V. M. (2015). Impact of access to credit on agricultural productivity: Evidence from smallholder cassava farmers in Nigeria. Paper presented at the International Conference of Agricultural Economists.

Barbosa, P. G. A., Martins, F. I. C. C., Lima, L. K., Milhome, M. A. L., Cavalcante, R. M., \& do Nascimento, R. F. (2018). Statistical analysis for quality adjustment of the analytical curve for determination of pesticide multiresidue in pineapple samples. Food Analytical Methods, 11(2), 466-478.Available at: https://doi.org/10.1007/s12161-017-1017-9.

Chiguvi, D. (2020). The influence of after sales services on marketing performance in the retail sector in Botswana. Dutch Journal of Finance and Management, 4(1), 1-8.Available at: https://doi.org/10.29333/djfm/8361.

Cingano, F., Leonardi, M., Messina, J., \& Pica, G. (2016). Employment protection legislation, capital investment and access to credit: Evidence from Italy. The Economic Journal, 126(595), 1798-1822.Available at: https://doi.org/10.1111/ecoj.12212.

Creamer, E. (2015). The double-edged sword of grant funding: A study of community-led climate change initiatives in remote rural Scotland. Local Environment, 20(9), 981-999.Available at: https://doi.org/10.1080/13549839.2014.885937.

Creswell, J. W., \& Creswell, J. D. (2017). Research design: Qualitative, quantitative, and mixed methods approaches (pp. 1-270): Sage Publications.

Duguma, G. J., \& Han, J. (2018). Effect of deposit mobilization on the financial sustainability of rural saving and credit cooperatives: Evidence from Ethiopia. Sustainability, 10(10), 1-23.Available at: https://doi.org/10.3390/su10103387.

Dvouletý, O., Srhoj, S., \& Pantea, S. (2020). Public SME grants and firm performance in European Union: A systematic review of empirical evidence. Small Business Economics, 14, 1-21.Available at: https://doi.org/10.1007/s11187-019-00306-x.

Fotiadis, A., Nuryyev, G., Achyldurdyyeva, J., \& Spyridou, A. (2019). The impact of EU sponsorship, size, and geographic characteristics on rural tourism development. Sustainability, 11(8), 1-15.Available at: https://doi.org/10.3390/su1 1082375.

Fu, Y., \& Cheng, X. (2010). Analysis on after-sales service management of agricultural machinery. Agriculture Eீ Technology, 30(6), $96-97$.

Han, J. (2005). Analysis on the management of after - sales service of agricultural machinery products. Non Coexistence MU goes to Ji Shoe Flower, 04, 39-40.

Heikkilä, A., Kalmi, P., \& Ruuskanen, O.-P. (2016). Social capital and access to credit: Evidence from Uganda. The Journal of Development Studies, 52(9), 1273-1288.Available at: https://doi.org/10.1080/00220388.2016.1139695.

Heyer, J., Schmitt, Z., Dombrowski, L., \& Yarosh, S. (2020). Opportunities for enhancing access and efficacy of peer sponsorship in substance use disorder recovery. Paper presented at the Conference on Human Factors in Computing Systems - Proceedings.

Hossain, M. G., Zyroul, R., Pereira, B., \& Kamarul, T. (2012). Multiple regression analysis of factors influencing dominant hand grip strength in an adult Malaysian population. Journal of Hand Surgery, 37(1), 65-70.Available at: https://doi.org/10.1177/1753193411414639.

Keith, T. Z. (2019). Multiple regression and beyond: An introduction to multiple regression and structural equation modeling. In Multiple Regression and Beyond: An Introduction to Multiple Regression and Structural Equation Modeling. In T. Francis (Ed.), (pp. 1-639): Taylor \& Francis.

Kidd, L., Wengstro, Y., \& Ulrika, O. (2011). Combining qualitative and quantitative research within mixed method research designs : A methodological review. International Journal of Nursing Studies, 48, 369-383.Available at: https://doi.org/10.1016/j.ijnurstu.2010.10.005

Kirui, O., \& Braun, v. J. (2018). Mechanization in African agriculture: A continental overview on patterns and dynamics. Center for Development Research, University of Bonn. 1-22. Available at: SSRN 3194466 (2018).

Littlejohn, C., \& Dutant, J. (2020). Justification, knowledge, and normality. Philosophical Studies, 177(6), 1593-1609.Available at: https://doi.org/10.1007/s 1 1098-019-01276-2. 
Lundh, A., Lexchin, J., Mintzes, B., Schroll, J. B., \& Bero, L. (2017). Industry sponsorship and research outcome. Cochrane Database of Systematic Reviews Methodology, 2(2), 1-140.Available at: https://doi.org/10.1002/1465 1858.MRo00033.pub3.

Mabururu, K. N., \& Wekesa, S. (2020). Factors influencing the effectiveness of youth enterprise development fund in Kapseret Constituency, Uasin Gishu County, Kenya. International Academic Journal of Information Sciences and Project Management, $3(6), 222-244$.

Melzer, B. T., \& Morgan, D. P. (2015). Competition in a consumer loan market: Payday loans and overdraft credit. Journal of Financial Intermediation, 24(1), 25-44.Available at: https://doi.org/10.1016/j.jfi.2014.07.001.

Mladenka, B., Slobodan, Ž., \& Periša, I. (2016). Sources of finance for development. Economic Analysis, 49(1-2), 48-58.Available at: https://doi.org/10.1007/BFo2925856.

Mmbengwa, V., \& Qin, X. (2020). Problem and advice of rural poverty-alleviation in China amid the epidemic of covid-19. Journal of Human Ecology, 71 (1-3), 62-72.Available at: https://doi.org/10.31901/24566608.2020/71.1-3.3234.

Morrissey, M. B., \& Ruxton, G. D. (2018). Multiple regression is not multiple regressions: The meaning of multiple regression and the non-problem of collinearity. Philosophy, Theory, and Practice in Biology, 10(3), 1-24.Available at: https://doi:10.3998/ptpbio.16039257.0010.003.

Mrema, G., Kienzle, J., \& Mpagalile, J. (2018). Current status and future prospects of agricultural mechanization in sub-saharan Africa (SSA). Agricultural Mechanization in Asia, Africa and Latin America, 49(2), 13-30.

Murali, S., Pugazhendhi, S., \& Muralidharan, C. (2015). Evaluation of performance of after sales service-a comparative study involving home appliances manufacturing firms. ARPN Journal of Engineering and Applied Sciences, 20(13), 5614-5619.

Ngo, T. H. D., \& Puente, C. A. L. (2012). The steps to follow in a multiple regression analysis. Paper presented at the SAS ${ }$ Global Forum 2012 Conference.

Ogundeji, A. A., Donkor, E., Motsoari, C., \& Onakuse, S. (2018). Impact of access to credit on farm income: Policy implications for rural agricultural development in Lesotho. Agrekon, 57(2), 152-166.Available at: https://doi.org/10.1080/03031853.2018.1483251.

Omondi-Ochieng, P. (2020). Financial performance of the United Kingdom's national non-profit sport federations: A binary logistic regression approach. Managerial Finance.Available at: https://doi.org/10.1108/MF-03-2020-0126.

Pallant, J. (2020). Multiple regression. In SPSS survival manual (pp. 153-174): Routledge.

Potkány, M., Stasiak-Betlejewska, R., Kováč, R., \& Gejdoš, M. (2016). Outsourcing in contidions of SMEs - the potential for cost savings. Polish Journal of Management Studies, 13(1), 145-156.Available at: https://doi.org/10.17512/pjms.2016.13.1.14.

Qin, X., Pretorius, L., \& Jiang, D. (2019). A review of after-sales service practice of Chinese agricultural machinery in cross-border E-commerce in Africa (PICMET). Paper presented at the PICMET 2019 - Portland International Conference on Management of Engineering and Technology: Technology Management in the World of Intelligent Systems, Proceedings.

Qin, X., Zhang, T., \& Mmbengwa, V. M. (2020b). The impact of after-sales service promotion of agricultural machinery on SubSaharan African agri-economy. Basic \& Clinical Pharmacology \& Toxicology, 127(X), 62-65.

Rani, D. K. (2016). A brief review of tests for normality. American Journal of Theoretical and Applied Statistics, 5(1), 5-12.Available at: https://doi.org/10.11648/j.ajtas.20160501.12.

Saunders, M., Lewis, P., \& Thornhill, A. (2016). Research methods for business students (7th ed.). Nueva York: Pearson Education.

Schmidt, A. F., \& Finan, C. (2018). Linear regression and the normality assumption. Journal of Clinical Epidemiology, 98, 146151.Available at: https://doi.org/10.1016/j.jclinepi.2017.12.006.

Shokouhyar, S., Shokoohyar, S., \& Safari, S. (2020). Research on the influence of after-sales service quality factors on customer satisfaction. Journal of Retailing and Consumer Services, 56(March), 102139.Available at https://doi.org/10.1016/j.jretconser.2020.102139.

Sims, B., \& Kienzle, J. (2016). Making mechanization accessible to smallholder farmers in Sub-Saharan Africa. Environments, 3(2), 11.Available at: https://doi.org/10.3390/environments3020011.

Terrell, S. R. (2012). Mixed-methods research methodologies. Qualitative Report, 17(1), 254-280.

Valaskova, K., Kliestik, T., \& Kovacova, M. (2018). Management of financial risks in Slovak enterprises using regression analysis. The Economy Copcrnicana, 9(1), 105-121.Available at: https://doi.org/10.24136/oc.2018.006.

Van Loon, J., Woltering, L., Krupnik, T. J., Baudron, F., Boa, M., \& Govaerts, B. (2020). Scaling agricultural mechanization services in small-holder farming systems: Case studies from sub-Saharan Africa, South Asia, and Latin America. Agricultural Systems, 180. 1-13.Available at: https://doi.org/10.1016/j.agsy.2020.102792.

Wieliczko, B., Kurdyś-Kujawska, A., \& Sompolska-Rzechuła, A. (2020). Savings of small farms: Their magnitude, determinants and role in sustainable development example of Poland. Agriculture, 10(11), 525.Available at https://doi.org/10.3390/agriculture10110525.

Yang, K., Tu, J., \& Chen, T. (2019). Homoscedasticity: An overlooked critical assumption for linear regression. General Psychiatry, 32(5), 1-5.Available at: https://doi.org/10.1136/gpsych-2019-100148.

Yarnold, P. R., \& Bennett, C. L. (2016). Novometrics vs. multiple regression analysis: Age and clinical measures of PCP survivors. Age, 1(38.01), 7-92.

Zhang, C. (2010). The role of after-sales service in agricultural marketing. Shihezi Technology, 3, 40-41.

Zhang., T., \& Qin, X. (2020). The impact of the covid-19 on China's rural revitalization. Basic \& Clinical Pharmacology \& Toxicology, $127(\mathrm{Y}), 110-113$. 